\title{
Winter beef weight gain on Italian grass seed crops in South Canterbury
}

\author{
M.D. CRAIGHEAD ${ }^{1}$, J.A. HAYWARD ${ }^{1}$ and W.B. BURGESS ${ }^{2}$ \\ ${ }^{1}$ Ravensdown Fertiliser Co-operative Ltd, PO Box 1049, Christchurch
}

\begin{abstract}
Italian grass seed crops grown in South Canterbury were used as intensively grazed winter greenfeed for weaner Angus or Angus cross steers in 19941996. The aim was to achieve good liveweight gain between April and October and in the process control the excess bulk on the crop. thereby spreading the economic risk associated with relying on the crops income coming from seed. Over this period, liveweight gains of $0.9,0.9$ and $1.0 \mathrm{~kg} / \mathrm{head} /$ day were achieved. Cattle were sold in early October to coincide with spikelet initiation, the optimum time to close the crop for seed. This enabled us to supply cattle on contract to a market prepared to pay a bonus for animals at the right weight and age. The crop was sown earlier than normal to build up a bank of feed ahead of the steers. Steers were shifted twice daily and backfenced to allow regrowth and the use of nitrogen fertiliser. Pasture quality and supply was closely monitored to optimise intake. Seed yields were maintained at about $1200 \mathrm{~kg} / \mathrm{ha}$ during the three years.
\end{abstract}

Keywords: Angus steers, grass seed production, Italian ryegrass, liveweight gain, nitrogen fertiliser, pasture growth, pasture quality, pasture utilisation

\section{Introduction}

Italian ryegrasses were primarily bred for cool-season feed for livestock. This study, utilising grass seed paddocks, was an attempt to bring together all the available performance and management information and apply it on a commercial paddock scale. No experimental treatments were used. Rather, two benchmarks were chosen against which the success of the study could be judged: $1 \mathrm{~kg} /$ day average liveweight gain of weaner steers from April to October (considerably above the South Island average of about $0.4-0.7 \mathrm{~kg} /$ day); and grass seed yields that matched previous farm seed yields. Intense monitoring was to be used to assess progress and adjust management as necessary. Replication was to be achieved by repeating the study over a number of years.

Tetraploid annual ryegrasses such as Grasslands
Tama have long been used by farmers for winter greenfeed. Typical winter dry matter production for South Canterbury has been quoted as $14-55 \mathrm{~kg} \mathrm{DM} /$ day under continuous cutting (Douglas 1985) and 40-60 kg/ha/day by Vartha at Winchmore under irrigation (Vartha \& Allison 1973; Vartha \& Bailey 1974), although it does drop to $10-20 \mathrm{~kg} \mathrm{DM} /$ day in late winter. Italian ryegrasses such as Concord, Corvette and Cordura are noted for their winter production and can outperform Tama (M. Norriss, pers. comm.). Their feed value is comparable to that of cereal greenfeeds (Ulyatt et al. 1980), but with the advantage that they can be repeatedly grazed. If reliable winter weight gains could be achieved on these crops it raises the possibility of either not having to winter revenue stock for a second winter, or that farmers could achieve early market premiums for stock in the spring after weaning.

Italian ryegrass seed crops are normally sown in Canterbury in March and April with some nitrogen. The winter activity of Italian ryegrasses means growth must be controlled by grazing and topping before the crop is closed at spikelet initiation for seed production. Excessive vegetative bulk increases the losses of seed within the windrow and through the harvester, particularly when harvest conditions are poor. Seed production is also compromised by wet spring and early summer conditions which lead to secondary tillers, for as the plant readily sheds seed at harvest it is not possible to wait for secondary seed-heads to mature. Hence winter grazing offers a viable option for farmers to manage winter growth and further diversify income between feed and seed income.

\section{Methods}

The study was carried out at Seadown, South Canterbury on irrigated Lismore stony silt loams, a yellow-grey earth on the New Zealand Genetic Classification (or a Pallic soil as an approximate equivalent in the New Zealand Soil Classification of Hewitt 1992). The study was repeated in three consecutive seasons, 1994-1996.

Each year, Italian ryegrass seed crops were sown in late January in paddocks of 6-6.5 ha. Crops always followed a process pea crop harvested by the new year, as this gave a reliability of sowing date. Nitrogen was always applied at planting, with further sidedressings as 
required to maintain a bank of feed. Weaner steers were introduced at the beginning of April and kept until early October (approximately 180 days). Wrightson Seeds Corvette (1994) or Cordura $(1995,1996)$ Italian ryegrasses were sown at $20 \mathrm{~kg} / \mathrm{ha}$ with $200 \mathrm{~kg} / \mathrm{ha}$ of Cropmaster 20 (providing $40 \mathrm{~kg} \mathrm{~N}, 20 \mathrm{~kg} \mathrm{P}$ and $25 \mathrm{~kg} \mathrm{~S} /$ ha) broadcast before sowing. One year selenium prills, 1 $\mathrm{kg} / \mathrm{ha}$, were sown in 1995 and 1996. Specific paddock details were as follows;

1994 Sowing date: 22 January.

Soil test: pH 6.1, Olsen P 31, QTK 10, $\mathrm{SO}_{4}-\mathrm{S}$ 11.

Irrigation: $28 \mathrm{~mm} 9$ February, $22 \mathrm{~mm}$ late May, $28 \mathrm{~mm}$ mid September.

Additional N applied: First grazing; $32 \mathrm{~kg} \mathrm{~N} / \mathrm{ha}$ (70 kg/ha of urea) 9 February, $34 \mathrm{~kg} \mathrm{~N} / \mathrm{ha}$ (125 $\mathrm{kg} / \mathrm{ha}$ of calcium ammonium nitrate, CAN) $2 \mathrm{nd}$ week of March. Second grazing; $40 \mathrm{~kg} \mathrm{~N} / \mathrm{ha}$ (85 $\mathrm{kg}$ of urea) applied to $80 \%$ of paddock in four separate dressings as sufficient area became available.

1995 Sowing date: 30 January.

Soil test: pH 6.1, Olsen P 33, QTK 17, $\mathrm{SO}_{4}-\mathrm{S}$ 12, QTMg 23.

Irrigation: $28 \mathrm{~mm} 7$ March.

Additional $\mathrm{N}$ applied: First grazing; $40 \mathrm{~kg} \mathrm{~N} / \mathrm{ha}$ $(87 \mathrm{~kg} / \mathrm{ha}$ of urea) $7 \mathrm{March}, 39 \mathrm{~kg} \mathrm{~N} / \mathrm{ha}(150 \mathrm{~kg} /$ ha of ammonium sulphate nitrate, ASN) 31 March. Second grazing; $40 \mathrm{~kg} \mathrm{~N} / \mathrm{ha}(145 \mathrm{~kg} / \mathrm{ha}$ of CAN) to half the paddock 9 June, the remainder 25 July.

1996 Sowing date: 18 January.

Soil test: pH 5.7, Olsen P 34, QTK 5, $\mathrm{SO}_{4}-\mathrm{S} 12$, QTMg 18 .

Irrigation: $25 \mathrm{~mm} 29$ January.

Additional N applied: First grazing; $46 \mathrm{~kg} \mathrm{~N} / \mathrm{ha}$ (100 kg/ha urea) 26 February. Second grazing; $40 \mathrm{~kg} \mathrm{~N} / \mathrm{ha}(150 \mathrm{~kg} / \mathrm{ha}$ CAN) to half the paddock 5 May, the remainder 8 June, $26 \mathrm{~kg} \mathrm{~N} / \mathrm{ha}$ to $40 \%$ of the paddock 8 August (100 kg/ha of ASN) and the remaining area 2 September $(95 \mathrm{~kg} / \mathrm{ha}$ of CAN).

\section{Stock}

Steers 6-7 months old were purchased at the Blue Cliffs Station weaner calf sale in late March each year, consistent in line, and of a narrow weight range. The numbers and initial liveweights were: $1994-20$ at 260 kg liveweight; $1995-24$ at $270 \mathrm{~kg} ; 1996-24$ at $265 \mathrm{~kg}$. Pure Angus were used in 1994 and 1996. In 1995, numbers were evenly split between Angus and Angus cross steers. Cattle were given Ivomec drench or bolus for internal parasite control and a 5 in 1 injection for disease. On arrival blood samples were taken for analysis, as a result of which vitamin $B_{12}$ was injected in 1994 and 1996, selenium (all years) and copper in 1995 and 1996. Blocare 4511 was added to the water from early spring in 1995 and 1996 as a consequence of losing a steer in September 1995.

\section{Feed management}

Stock were introduced in early April and fed behind an electric fence (on a 160-190 m front), moved twice daily, to reduce trampling and maximise intake. A back fence was also used 10-20 m behind to allow better utilisation of pasture and to maximise regrowth. The current feed on offer and the ungrazed residue was assessed by pasture cuts to $45 \mathrm{~mm}$ height. Feed was budgeted to produce on a metabolisable energy (ME) basis, liveweight gains of at least $1 \mathrm{~kg} /$ day (Geenty \& Rattray 1987). This was regularly monitored by grazing height pasture analysis. Daily ME requirements increased from $75 \mathrm{MJ}$ at $260-270 \mathrm{~kg}$ liveweight to $110 \mathrm{MJ}$ when cattle reached a contracted weight (over $400 \mathrm{~kg}$ ). This was initially achieved by 1 - to 2 -m breaks of feed. These breaks increased in the second (and third) grazings as growth slowed and cattle liveweight increased. Subsequent grazing became more lax once spring growth gave feed surpluses and the needs of the seed crop became more important. Feed supply was also adjusted to suit weather conditions. Some poor quality lucerne hay was provided in 1994, and ryegrass straw almost daily (1-2 bales), in 1995 and 1996 to provide roughage. Cattle were weighed weekly in 1994 and fortnightly in 1995 and 1996. Cattle were kept on the grass at all times (bar 2-3 days in 1995 to avoid pugging). In October, the paddock was topped to even it out, nitrogen applied and the crop closed for seed production.

\section{Results and discussion}

\section{Liveweight}

Liveweight gain was up to or exceeding our target of 1.0 $\mathrm{kg}$ /day for the first $12-14$ weeks, especially in the final year (Figure 1). Weight gain then declined to $0.7-0.8 \mathrm{~kg}$ for 3-5 weeks in mid winter before returning to $1.0 \mathrm{~kg}$ as grass growth improved. Final weight gains for the full period were $0.9 \mathrm{~kg}, 0.9 \mathrm{~kg}$ and $1.0 \mathrm{~kg} /$ day over the three years. Final liveweights averaged $423 \mathrm{~kg}, 437 \mathrm{~kg}$ and 447 $\mathrm{kg}$ respectively. In 1995 when pure Angus and Angus cross cattle were compared, there was little difference in production. Initially, the Angus put on more weight, but the Angus cross cattle had more than compensated for this by October. These weight gains compare well with the $0.45-0.85 \mathrm{~kg} /$ day quoted as typical for New Zealand 
by Nicol \& Coop (1970), for weaners fed predominantly on autumn-saved pasture.

In October, animals were sent to Five Star Beef Feedlot at Wakanui, Mid-Canterbury. Typically, this

Figure 1 Liveweight gain 1994-1996.

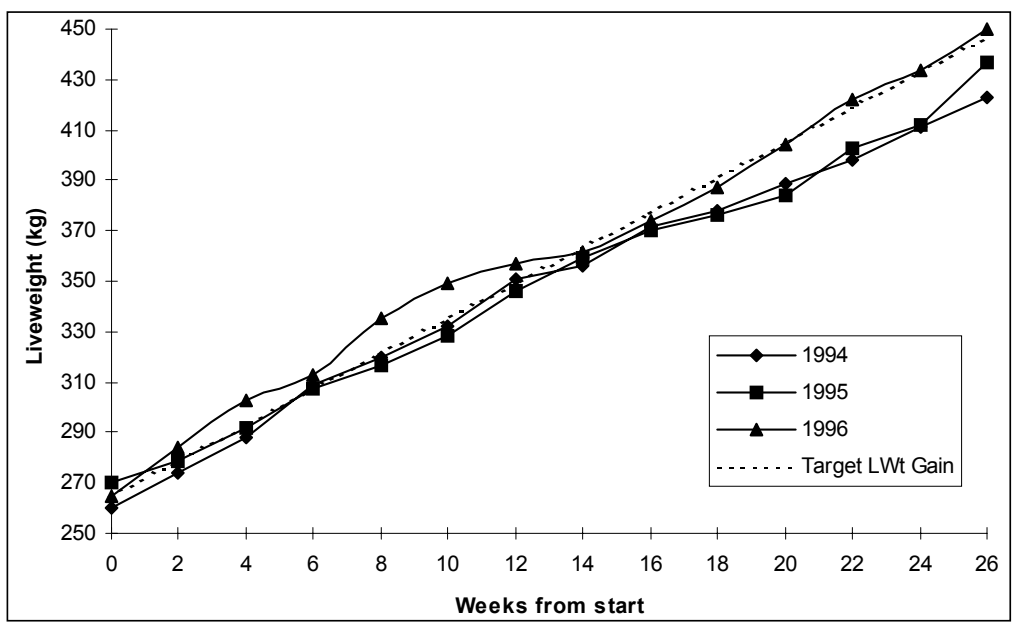

after ME falls below 11.0. The effect was more pronounced in 1995, as less feed was initially available necessitating tighter grazing, and a wet June caused some pugging and left higher resid-uals in part of the paddock. The ME values for the second grazing of these parts of the paddock reflect this, but not the protein values. Residual feed at other times usually ranged from 600 to $1000 \mathrm{~kg} \mathrm{DM} / \mathrm{ha}$ (above $45 \mathrm{~mm}$ ), although high-er residuals were deliberately left to the first grazing in 1996 to reduce the fluctuations in ME. In 1994 the poor weight gains also coincided with a cold southerly front in a more exposed paddock. In hindsight the cattle were underfed at this time.

The decline in weight gain also coincides with a change in diet associated with grazing regrowth. This occurred earlier

was several months earlier than other cattle. Here they averaged a further $1.0-1.2 \mathrm{~kg}$ /day liveweight gain on grain and silage. When killed at 18-19 months they weighed 650-750 kg. Production was: $1994-1.2 \mathrm{~kg}$ liveweight/day, dress out 57\%; $1995-1 \mathrm{~kg} /$ day, dress out $59.6 \% ; 1996-1.1 \mathrm{~kg} /$ day, dress out $58.4 \%$.

The decline in weight gain in winter is influenced by several factors. Its onset usually coincided with the lowest soil temperatures, hence the decline occurred earlier in 1996 (Tables 1-3). The crude protein values and more especially the ME values also show pasture quality declined towards the end of the first grazing (June/July). Weight gain usually declined 2-4 weeks in 1996 as regrowth was grazed early, and lasted longer in 1995 probably because of the prolonged drop in ME value. It is likely that the animals' gut bacteria were conditioned to the older, coarser feed and took time to adjust to the sudden change to higher value feed in the regrowth. In particular the regrowth contained excessive crude protein, so roughage was given to utilise this, rather than the animal excreting it as urea. Intake was likely to be lower as cattle still showed a preference for the older grass. This was demonstrated in June 1996 when the cattle were given the choice of fresh regrowth and old grass. Overall, while the crude protein values were often below the optimum suggested for fresh pasture

Table 1 Feed quality and dry matter on offer during 1994.

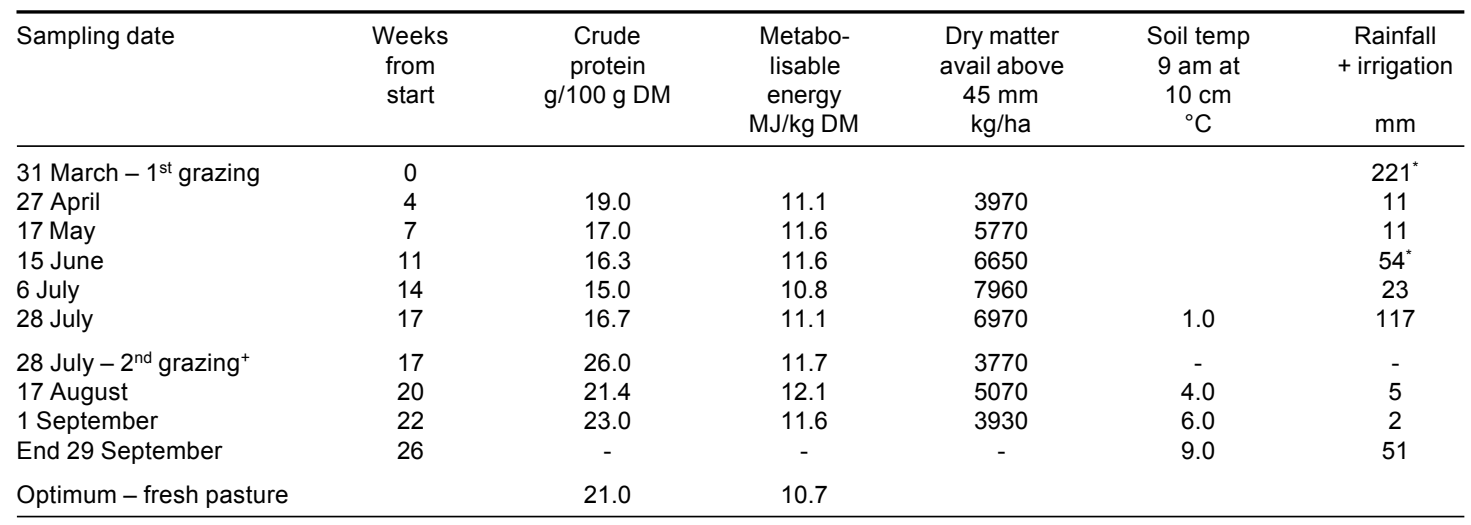

* includes irrigation, ${ }^{+}$fresh grass 
Table 2 Feed quality and dry matter on offer during 1995.

\begin{tabular}{|c|c|c|c|c|c|c|}
\hline Sampling date & $\begin{array}{l}\text { Weeks } \\
\text { from } \\
\text { start }\end{array}$ & $\begin{array}{c}\text { Crude } \\
\text { protein } \\
\mathrm{g} / 100 \mathrm{~g} \mathrm{DM}\end{array}$ & $\begin{array}{c}\text { Metabo- } \\
\text { lisable } \\
\text { energy } \\
\text { MJ/kg DM }\end{array}$ & $\begin{array}{c}\text { Dry matter } \\
\text { avail above } \\
45 \mathrm{~mm} \\
\mathrm{~kg} / \mathrm{ha}\end{array}$ & $\begin{array}{l}\text { Soil temp } \\
9 \text { am at } \\
10 \mathrm{~cm} \\
{ }^{\circ} \mathrm{C}\end{array}$ & $\begin{array}{c}\text { Rainfall } \\
+ \text { irrigation } \\
\text { mm }\end{array}$ \\
\hline 3 April $-1^{\text {st }}$ grazing & 0 & 28.3 & 12.1 & 2170 & & $148^{*}$ \\
\hline 4 May & 4 & 24.0 & 11.8 & 6350 & 12.0 & 32 \\
\hline 9 June & 9 & 17.1 & 11.6 & 6800 & 6.0 & 67 \\
\hline 6 July & 13 & 14.5 & 9.7 & 5970 & 4.0 & 160 \\
\hline 18 July $-2^{\text {nd }}$ grazing & 15 & 14.3 & 11.7 & 5870 & 1.8 & 17 \\
\hline 4 August & 17 & 20.6 & 10.6 & 3350 & 1.3 & 7 \\
\hline 24 August $-3^{\text {rd }}$ grazing & 20 & 24.6 & 10.0 & 1670 & 4.5 & 30 \\
\hline 11 Sept $-4^{\text {th }}$ grazing & 23 & 27.5 & 10.9 & $>450$ & 5.6 & 42 \\
\hline End 5 October & - & - & - & - & 9.2 & 62 \\
\hline
\end{tabular}

* includes irrigation

Table 3 Feed quality and dry matter on offer during 1996.

\begin{tabular}{|c|c|c|c|c|c|c|}
\hline Sampling date & $\begin{array}{l}\text { Weeks } \\
\text { from } \\
\text { start }\end{array}$ & $\begin{array}{c}\text { Crude } \\
\text { protein } \\
\mathrm{g} / 100 \mathrm{~g} \mathrm{DM}\end{array}$ & $\begin{array}{c}\text { Metabo- } \\
\text { lisable } \\
\text { energy } \\
\text { MJ/kg DM }\end{array}$ & $\begin{array}{c}\text { Dry matter } \\
\text { avail above } \\
45 \mathrm{~mm} \\
\mathrm{~kg} / \mathrm{ha}\end{array}$ & $\begin{array}{c}\text { Soil temp } \\
9 \mathrm{am} \text { at } \\
10 \mathrm{~cm} \\
{ }^{\circ} \mathrm{C}\end{array}$ & $\begin{array}{c}\text { Rainfall } \\
+ \text { irrigation } \\
\text { mm }\end{array}$ \\
\hline 1 April $-1^{\text {st }}$ grazing & 0 & 19.5 & 11.4 & 4200 & 10.7 & $234^{*}$ \\
\hline 6 May & 5 & 14.8 & 11.0 & 6500 & 8.7 & 81 \\
\hline 8 June & 10 & 12.5 & 10.5 & 7200 & 5.1 & 37 \\
\hline 23 June $-2^{\text {nd }}$ grazing ${ }^{+}$ & 12 & 19.8 & 12.0 & 3700 & 2.0 & 35 \\
\hline 24 July & 16 & 26.5 & 12.2 & 2800 & 4.3 & 94 \\
\hline 20 August & 20 & 23.3 & 12.1 & 2700 & 4.4 & 36 \\
\hline 12 Sept $-3^{\text {rd }}$ grazing & 23 & 24.2 & 12.2 & 1300 & 7.9 & 20 \\
\hline 28 Sept $-4^{\text {th }}$ grazing & 26 & & & 1500 & 9.1 & 7 \\
\hline End 7 October & - & - & - & - & 9.6 & 2 \\
\hline
\end{tabular}

* includes irrigation, ${ }^{+}$values relate to the regrowth and not the yet to be grazed part of the paddock

(21\%), particularly in 1994 and 1996, they were above the $10-14 \%$ generally accepted as the minimum to achieve growth (Ulyatt et al. 1980). Digestibility was always $68-76 \%$ and, where measured, acid detergent fibre (ADF) ranged from 20 to $29 \%$.

\section{Autumn feed supply and seed yield}

Sowing Italian ryegrass as greenfeed early ensures a larger bank of feed by April. This reduces the amount of autumn nitrogen required (such as used in 1995) to boost a marginal feed supply. Nitrogen fertilisers containing nitrate nitrogen were preferred for late autumn and winter nitrogen applications, since ongoing work on the farm showed these were more reliable than urea at cool soil temperatures (below $6^{\circ} \mathrm{C}$ ) (Craighead et al. 1997).

Autumn nitrogen at higher than traditional rates was not considered detrimental to the subsequent seed yields. In 1994, replicated plot trials on Corvette Italian ryegrass showed $60 \mathrm{~kg} \mathrm{~N} / \mathrm{ha}$ in autumn significantly increased seed yields $(\mathrm{P}=0.014)$ over nil or $30 \mathrm{~kg} \mathrm{~N} / \mathrm{ha}$ in autumn
(2.60 t/ha vs $2.32 \mathrm{t} / \mathrm{ha}$ and $2.35 \mathrm{t} / \mathrm{ha}$, before dressing). Equally, high nitrate levels in the herbage were not considered a major issue. Levels when monitored, were usually low $(<0.2 \%)$, although they did rise to $0.4-0.5 \%$ in May/June 1995. This did not seem to affect weight gain, probably because the cattle were conditioned to the feed and roughage was supplied.

\section{Grazing and seed yield}

It is hard to gauge the impact of grazing on grass seed performance. Grazing damage caused by pulling was not considered high and the stony soils helped reduce pugging. Damage was mainly confined to near the portable water trough and where the steers fought. Seed yields are influenced more by the amount of nitrogen used at closing and the climatic conditions at harvest. Ideally, crops should be windrowed at near $40 \%$ moisture and harvested at $18-20 \%$, then dried (M. Norriss, pers. comm.) In 1995 and 1996, harvest conditions were not ideal and losses were high. Therefore winter grazing could be considered a way of spreading the financial 
risk. Over the three years, there was little difference in yield for the paddock; $1994-1235 \mathrm{~kg} / \mathrm{ha}$ machine dressed; $1995-1225 \mathrm{~kg} / \mathrm{ha} ; 1996-1200 \mathrm{~kg} / \mathrm{ha}$. These yields compare favourably with previous and subsequent crop yields, $1320 \mathrm{~kg} / \mathrm{ha}$ in 1993, $1000 \mathrm{~kg} / \mathrm{ha}$ in 1997.

The summary data (Table 4 ) show that over the period of the study production/ha has increased. This reflects mainly an improvement in animal performance rather than stocking rate. Production could have increased further had spring growth been fully utilised with more animals. Despite this, our production in the 6 cooler months still compares favourably with the $1000 \mathrm{~kg}$ liveweight/ha/year often quoted for the cell system of beef production in which cattle are rotated between small blocks or cells.

It is hard to accurately estimate the dry matter produced, because the paddock is always in various stages of regrowth. Allowing for the estimated $1100 \mathrm{~kg} /$

Table 4 Summary of beef performance Ravendown Fertiliser Seadown Farm 1994-1996 (April-Oct).

\begin{tabular}{lccc}
\hline & 1994 & 1995 & 1996 \\
\hline Days grazed - start of April to early Oct & 182 & 183 & 182 \\
Initial liveweight (kg) & 260 & 270 & 265 \\
Final liveweight (kg) & 423 & 437 & 447 \\
Liveweight gain & 163 & 167 & 182 \\
Liveweight gain/day & 0.9 & 0.9 & 1.0 \\
Stocking rate (steers/ha) & 3.4 & 3.5 & 3.6 \\
Liveweight production (kg/ha) & 570 & 605 & 665 \\
Nitrogen used * & 140 & 160 & 152 \\
Estimated kg DM (end of Jan - early Oct) & $>10,500$ & $>9,500$ & $>10,000$ \\
Supplementary roughage & minimal & daily & daily \\
\hline
\end{tabular}
grass seed crop. herds.
* $40-80 \mathrm{~kg}$ of this $\mathrm{N}$ would normally be used in autumn to establish the

earlier liveweight on revenue stock must all be considered. The data presented here will assist in making those decisions.

\section{Conclusions}

This work has shown that good liveweight gains can be achieved by steers grazing Italian ryegrass seed crops in cool winter conditions.

Early achievement of target liveweights allows such opportunities as early market premiums for cattle, to carry stock for a shorter period, or to winter graze dairy

Italian ryegrass seed yields do not appear to be severely compromised as the grazing allowed control of the excess bulk, consistent with growing these crops.

Continuity of feed supply can be met by building up a bank of feed early, the use of autumn and winter nitrogen, and good feed management including strip grazing, the use of a back fence, herbage quality monitoring and the use of straw as roughage.

\section{ACKNOWLEDGEMENTS}

The authors thank Mr J. Bain for daily shifting of fences and feeding out, the staff at Seadown works for weekend and holiday shifting of fences, and to Mr A.M. Howie for the handling of pasture yield and quality samples. Also to A. Campbell of Ashbury Vets for his assistance and to MSD Agvet for providing product and advice.

\section{REFERENCES}

ha below the $45 \mathrm{~mm}$ height measured, then growth by July is $8000-9000 \mathrm{~kg}$, that is, at least $45 \mathrm{~kg} \mathrm{DM} / \mathrm{ha} /$ day since emergence. Hence the estimates to the end of September may be somewhat conservative. Allowing for minimal growth when soil temperatures were below $2{ }^{\circ} \mathrm{C}$, then peak growth in autumn and early spring growth is likely to be in excess of $70-80 \mathrm{~kg} \mathrm{DM} / \mathrm{ha} /$ day. This compares favourably with the data for Tama (Vartha \& Allison 1973), giving some indication of the potential of true Italian cultivars. The same should apply to the newer hybrids, such as Wrightson Seeds Maverick and Pyne Gould Guinness's Ceres Flanker.

Economics have been deliberately left out of this study, as each farm situation will be different. Stock type, purchase price (if indeed they need to be purchased), contract grazing prices, the intensity of grazing, whether a specialty greenfeed crop is grown or a seed crop is used, the amount of nitrogen required, the value put on supplements and the value placed on having
Craighead, M.D.; Hayward, J.A.; Howie, A.M. 1997. Evaluation of nitrate fertilisers as nitrogen sources for spring pasture. Proceedings of the New Zealand Grassland Association 59: 131-135.

Douglas, J.A. 1980. Yields of crops for forage and fodder. In: Drew, K.R.; Fennessy, P.F. (eds) Supplementary feeding. New Zealand Society of Animal Production. Occasional Report No. 7, Mosgiel.

Geenty, K.G.; Rattray, P.V. 1987. The energy requirements of grazing sheep and cattle. In: Nicol, A.M. (ed.) Livestock feeding on pasture. New Zealand Society of Animal Production, Occasional Publication No. 10, Hamilton.

Hewitt, A.E. 1992. New Zealand Soil Classification, DSIR Land Resources Scientific Report No. 19. DSIR Land Resources, Lower Hutt.

Nicol, A.M.; Coop, I.E., 1970. Nutrition of growing 
beef cattle. In: Campbell, A.G. (ed.) New Zealand beef production, processing and marketing. Wellington: New Zealand Institute of Agricultural Science.

Ulyatt, M.J.; Fennessy, P.F.; Rattray, P.V.; Jagusch, K.T. 1980. The nutritive value of supplements. In: Drew, K.R.; Fennessy, P.F. (eds) Supplementary feeding. New Zealand Society of Animal Production. Occasional Report No. 7, Mosgiel.

Vartha, E.W.; Allison, R.M. 1973. Extractable protein for 'Grasslands Tama' Westerwolds ryegrass. New
Zealand journal of experimental agriculture 1:239242.

Vartha, E.W.; Bailey, R.W. 1974. Soluble carbohydrate composition of a winter grown tetraploid annual ryegrass 'Grasslands Tama' Westerwolds. New Zealand journal of experimental agriculture 2: $17-$ 22. 